\title{
Perspective
}

\section{A Perspective on Thalassaemia}

\author{
Zeeshan Hussain*, Saqib Ansari, Tahir Shamsi \\ National Institute of Blood Disease \& Bone Marrow Transplantation, Karachi, Pakistan.
}

\section{THALASSAEMIA SYNDROME (TS)}

TS is a varied group of genetic disorder results from reduced rate of synthesis of alpha or beta globin chains. Its inheritance is autosomal recessive [1]. Thalassaemias are considered most prevalent genetic disorders worldwide; mostly they occur in tropics and sub-tropics but now sporadic cases are prevalent in other regions of the globe also, mainly due to resettlements across the continents $[2,3]$. Almost all ethnic groups of Pakistan represent beta thalassaemia in their community and its carrier rate is estimated to be 5-8 \% [4]. The alpha thalassaemia which is comparatively infrequent in the country but northern areas have relatively higher carrier rate for alpha thalassaemia which is roughly $2.4 \%$ [5]. Unfortunately there is no official registry of thalassaemia, so there is much paradox regarding the prevalence and incidence of thalassaemia patients in Pakistan. It is estimated from various sources based on number of patients registered at different thalassaemia centres, total number of patients is more than one hundred thousand and 5000-6000 thousands new borns fall prey to this deadly disorder each year. Although a higher number is claimed because a significant number of patients die undiagnosed and are unaccounted for.

\section{BETA THALASSAEMIA MAJOR (BTM)}

BTM (also well-known as Mediterranean or Colley's anaemia), is caused by reduced or absent beta globin chain formation as a consequent of homozygous mutations in beta globin genes. It occurs when two beta thalassaemia carriers marry each other and according to the probability of autosomal recessive diseases there are $25 \%$ chances of having a thalassaemia major child, $50 \%$ carrier or trait and $25 \%$ normal at every pregnancy. Over 392 different genetic mutations causing beta thalassaemia phenotype have been detected. It excludes all other variants including beta chain variants [6]. Specific mutations runs in specific ethnic groups, facts and data of these mutations helps a lot in antenatal diagnosis of this disorder, accordingly prevention is possible. At 10-12 weeks of conception, chorionic villous sampling (CVS) and later DNA analysis by ARMS PCR, molecular diagnosis of thalassaemia major, minor or normal can be made with high accuracy $[7,8]$.

In beta thalassaemia major ineffective erythropoiesis and

*Address correspondence to this author at the National Institute of Blood Disease \& Bone Marrow Transplantation, Karachi, Pakistan.

E-mail: zeeshan79ha@hotmail.com, zeeshan.share@gmail.com haemolysis is mainly due to excess alpha chains precipitation in newly producing erythroblasts in bone marrow. Clinical signs \& symptoms appear approximately after 3-6 months of age because of compensatory fetal haemoglobin presence. Unlike $\mathrm{Hb}$ Barts/Hydrops Foetalis (alpha thalassaemia major) beta thalassaemia major (BTM) does not causes intra-uterine death. After symptoms appear patient needs regular blood transfusion for the rest of his/her life to sustain. Clinically patient present with microcytic hypochromic anaemia, marked poikilocytosis along with irregularly contracted RBCs and red cell precursors on peripheral film morphology. If not treated properly the infants become progressively pale, fail to thrive, and caught recurrent fever and diarrhoea. Abdomen enlarges due to enlargement of liver and spleen by extramedullary haematopoiesis $[9,10]$. Conventional treatment i.e. regular transfusion has its own sequels which are iron overload, transfusion associated transmission of viral infections (most importantly Hepatitis B\&C), chronic liver disease and endocrine problems [10]. If treated properly with transfusion \& iron chelation along with all the complications appropriately addressed, patient may live up to 4 th decade of life.

\section{THALASSAEMIA INTERMEDIA (TI)}

This cluster encompasses homozygous beta thalassaemia patients which presents with milder clinical severity. They have moderate anaemia and sustain a haemoglobin level of $7-9 \mathrm{gm} / \mathrm{dl}$ and are mostly transfusion free. Symptoms initiation varies between 2-6 years, sometime more lately. It is fairly a clinical condition instead. Interestingly extra-medullary haematopoiesis, leg ulcers, gallstones and thrombophilia is more frequent in TI than BTM. TI patients require occasional blood transfusion though there is still no clear cut guideline of initiating transfusion therapy to prevent complications $[11,12]$. TI phenotype may be due to many reasons that include homozygous BTM with left-over $\mathrm{Hb}$ F, concurrence of alpha thalassaemia with BTM minimizing alpha chains imbalance and presence of $\beta+$ or $\beta++$ type of mutations. TI patients do require iron chelation despite seldom requirement of blood transfusion.

\section{BETA THALASSAEMIA TRAIT (BTT)}

BTT is more commonly recognised as thalassaemia carrier or thalassaemia minor. Molecular basis of this condition is presence of beta thalassaemia mutation in heterozygous state 
i.e. only single beta globin allele is mutated. This is usually a symptomless condition characterized by a blood picture of low $\mathrm{MCV}$, low $\mathrm{MCH}$ and a RBC count of $>5.5$ million/mm3. Haemoglobin is usually above $10 \mathrm{gm} / \mathrm{dl}$. These people are transfusion independent. It is diagnosed on the basis of raised $\mathrm{Hb}$ A2 i.e. $>3.4 \%$ (normal 1.5-3.4\%) on haemoglobin electrophoresis. Concomitant iron deficiency anaemia may decrease the A2 levels and a diagnosis of BTT could be overlooked. In such situations, iron replacement therapy should be started for 2-3 months and then the case is re-investigated $[10,13]$. When two individuals having BTT marry each other there are $25 \%$ chances of having a BTM child at each pregnancy.

\section{DIAGNOSIS OF BTM \& BTI}

Criteria and procedure for the diagnosis of BTM \& BTI is same; it includes $\mathrm{CBC}$ with peripheral blood morphology, $\mathrm{Hb}$ electrophoresis/HPLC and DNA Analysis. Peripheral blood smear morphology reveals marked poikilocytosis including irregularly contracted RBCs and red cell precursors. On $\mathrm{Hb}$ electrophoresis Feta $\mathrm{Hb}$ is usually $>90 \%$ ( normal range < $1 \%$ ) and DNA analysis shows specific mutations [10].

\section{UPDATES ON THALASSAEMIA TREATMENT \& CURE}

Besides conventional treatment of regular transfusion, allogeneic haematopoietic stem cell transplantation(AHSCT) is now a well documented cure for BTM and currently being practiced across the globe [14, 15]. Though high cost, technical difficulties like unavailability of matched donor still make it a difficult option and unavailable to every patient. Moreover graft versus host disease and graft rejection is also a major concerned of this procedure. To minimise the problems of laborious AHSCT, lentiviral $\beta$-globin gene transfer has been performed successfully in a sickle-beta thalassaemia patient having severe phenotype (dependent on monthly transfusions) with autologous HSCT, he is now transfusion independent and maintaining an $\mathrm{Hb}$ of $9-10 \mathrm{mg} / \mathrm{dl}$ [16-18]. Soon, globin gene editing and correction with Crispr-Cas9 for treating thalassaemias and other haemoglobinopathies would also be added to the list of cure $[19,20]$.

As far as other treatments are concerned fetal $\mathrm{Hb}$ augmenting agents are now widely used and hydroxyurea has gained immense popularity among the list. It is now established; in vitro as well as in vivo that hydroxyurea increases fetal haemoglobin levels that compensates for decrease adult haemoglobin. Its use in BTM patients has shown not only significant reduction in transfusion requirement but also shown transfusion independency [21-25].

\section{THALASSAEMIA PREVENTION - GLOBAL SCENARIO}

High cost research in search for cure, supportive treatment and overburdening of healthcare systems enormously necessitated the need for diseases prevention programs not limited to genetic disorders but also for other illnesses. These programs were initiated in seventies. Immense global efforts have been made to prevent Thalassaemia. Special carrier screening programs were started. WHO published a guideline in 1998 and stated that no compulsory genetic testing should be carried out [26]. Though some countries opted for mandatory premarital screening for thalassaemia and other haemoglobinopathies and have laws in place, these include Iran, Saudi Arabia, UAE, Palestinian, and Cyprus. People need to have an approval to get married. As a result significant decrease is noted in the birth of thalassaemic children in these countries especially in Iran. But in western countries such screening for any germ line disease is still voluntary [27].

A successful prevention programs needs mass education, mass screening, pre-marital screening (high school \& college students), extended family screening of the index child, prenatal diagnosis and termination of pregnancy. Mandatory screening is likely to be more beneficial in countries where thalassaemia is more prevalent i.e. Sub Mediterranean, Middle Eastern, South Asian, and Far Eastern countries [28-31].

\section{ABORTION- RELIGIOUS \& SOCIAL CONCERN}

As far as termination of pregnancy is concerned which is inevitable in the case where foetus is suffering from BTM, extreme viewpoints exist. Furthermore when a life is at question various groups of the society including social scientists, medical scientists, law makers, religious scholars and political leader all have their own opinion on the subject matter and everyone's perspective is taken into consideration before setting any standards in the society.

A faction of the society across the globe still thinks that under no situation or condition parents have the right to decide the fate of the pregnancy. Society should take care and support the child as well as the family. Contrary to the previous one, the other school of thought thinks that a complete knowledge about the expected outcome of the pregnancy must be informed to the parents and final decision of opting abortion or carrying on the pregnancy should honestly be left on the parents. They think that a life with pain and misery need to be stopped. Let's have an overview regarding opinions different religions (majorly practicing) have on the subject of pregnancy termination.

Generally all major religions (Islam, Christianity, Hinduism, Judaism and Buddhism) have their opinions against abortion; to them the subject incorporates profound debate of life and 
death, and morals that make the human society. They find that purely intellectual argument is unsatisfying about it. Orthodox Church although support carrier screening and pre-natal diagnosis. Unluckily, except Islam all other religion has their pre-determined laws \& principles that can never be changed and they have no religio-academic system to cope up the problems and the solutions modern scientific research is providing. They lack in defining aforesaid subject within the purview of religious jurisprudence, hence unable to remove the religious obstacle regarding carrier screening, pre-natal diagnosis \& elective abortion. Although practices in every country depends on the country's laws prevail in. But religion has still its own moral standing in every region of the world. Modern world where laws are mainly secular, leave this issue solely on "individual's right to decide". It is exclusively the responsibility of the couple to decide the fate of the pregnancy. They must be informed honestly regarding the outcome of the pregnancy and counselled impartially [32].

Luckily in Islam there is complete section of Islamic jurisprudence known as 'Ijtehad' and 'Ijmah' which deals with every type of difficult situation society faces and provides a platform for deliberating the solutions modern scientific research presents. The process involves the discussion of the issue among top religious scholar and subject specialist and a consensus is reached ultimately, giving a most suitable way out. All the proceedings are documented and it is always maintained that the spirit of very basic principles of Islam is not subverted or deteriorated. As far as abortion in thalassaemia and other fatal genetic disorders are concerned, all the sects within Islam clearly states that abortion may be opted by the couple in case of having a pregnancy with severe fetal defects provided that it is performed before 120 days. In Quran Allah says;

"And verily We did create man from a quintessence (of clay). Then We placed him (as a drop of sperm) in a place of rest, firmly fixed. Then We made the sperm into a clot of congealed blood. Then of that clot We made a (foetus) lump. Then We made out of that lump bones and clothed the bones with flesh. Then We developed out of it another creature (by breathing life into it). So blessed be Allah, the most marvellous Creator" (Sura al-Mu'minun V: 12-13-14).

There are clearly Ahadith regarding this 120 days time period. Sayyiduna Abd Allah ibn Mas'ud (Allah be pleased with him) narrates that the Messenger of Allah (Allah bless him \& give him peace) said:

"Each one of you is constituted in the womb of the mother for forty days, and then he becomes a clot of thick blood for a similar period, and then a piece of flesh for a similar period. Then Allah sends an angel who is ordered to write four things. He is ordered to write down his deeds, his livelihood, his (date of) death, and whether he will be blessed or wretched (in religion). Then the soul is breathed into him..." (Sahih al-Bukhari no: 3036).

Based on the above Quranic verse and Hadith, the jurists have inferred that the soul enters the foetus at around 4 months/120 days after gestation.

\section{THALASSAEMIA PREVENTION IN PAKISTAN}

A thalassaemic child lives around 10 to 12 years averages in our country. For ideal management of a BTM child enough safe blood supply and comprehensive management of iron chelation along with other complication is inevitable. The accumulative cost of this treatment reaches approximately to 3000 US \$ per patient annually. Whereas the per capita income of a Pakistani is approximately 1513 US \$ [33]. Due to the high cost majority of the patient in the country suffering from BTM are receiving substandard and insufficient treatment [34].

Carrier screening and pre-natal diagnosis is of utmost importance in current scenario of Pakistan. A country of this huge number of people ( $>200$ million) cannot be screened straight forward. A careful strategy need to be followed.

Below is the stepwise approach looks most feasible.

1. Extended Family screening of the index cases as $31 \%$ of the relative of thalassaemics are carriers [4].

2. Screening of the couple at the time pregnancy registrations or at ante-natal clinics.

3. Pre-natal diagnosis should be available to every couple at risk of having a BTM child \& appropriate genetic counselling may be provided regarding the outcomes [35].

4. Screening and awareness of high schools and college students as they are likely to be married soon.

5. Create awareness in masses for voluntary screening.

Working on many fronts simultaneously may decrease the incidence and prevalence of thalassaemia significantly, locally as well as globally.

\section{CONFLICT OF INTEREST}

Declared None.

\section{ACKNOWLEDGEMENTS}

Declared None.

\section{REFERENCES}

[1] Weatherall DJ, Clegg JB. The thalassaemia syndromes. USA: John Wiley \& Sons 2008.

[2] Weatherall D, Clegg JB. Inherited haemoglobin disorders: An increasing global health problem. Bull World Health Org 2001; 79: 704-12. 
[3] Modell B, Darlison M. Global epidemiology of haemoglobin disorders and derived service indicators. Bull World Health Org 2008; 86(6): 480-7. DOI: 10.2471/BLT.06.036673

[4] Ahmed S, Saleem M, Modell B, Petrou M. Screening extended families for genetic hemoglobin disorders in Pakistan. New Engl J Med 2002; 347(15): 1162-8.

DOI: $10.1056 / \mathrm{NEJMsa013234}$

[5] Rehman Z, Saleem M, Alvi A, Anwar M, Ahmed P, Ahmad M. Alpha-thalassaemia: Prevalence and pattern in northern Pakistan. J Pakistan Med Assoc 1991; 41(10): 246-7.

[6] Itha Genes [Internet]. [cited 23/05/2018]. Available from: Alpha-thalassaemia: prevalence and pattern in northern Pakistan.

[7] Ahmed S, Petrou M, Saleem M. Molecular genetics of beta-thalassaemia in Pakistan: A basis for prenatal diagnosis. Br J Haematol 1996; 94(3): 476-82.

[8] Ansari SH, Shamsi TS, Ashraf M, et al. Molecular epidemiology of $\beta$-thalassemia in Pakistan: Far reaching implications. Int J Mol Epidemiol Genetics 2011; 2(4): 403.

[9] Campbell JS. Alpha and beta thalassemia. Am Fam Physician 2009; 80(4).

[10] Galanello R, Origa R. Beta-thalassemia. Orphanet J Rare Dis 2010; 5(1): 11. DOI: 10.1186/1750-1172-5-11

[11] Taher A, Isma'eel H, Cappellini MD. Thalassemia intermedia: Revisited. Blood Cells Mol Dis 2006; 37(1): 12-20.

DOI: 10.1016/j.bcmd.2006.04.005

[12] Murru S, Loudianos G, Deiana M, et al. Molecular characterization of beta-thalassemia intermedia in patients of Italian descent and identification of three novel beta-thalassemia mutations. Blood 1991; 77(6): 1342-7.

[13] Galanello R, Melis M, Ruggeri R, et al. $\beta^{\circ}$ Thalassemia trait in Sardinia. Hemoglobin 1979; 3(1): 33-46.

DOI: $10.3109 / 03630267909069153$

[14] Lawson SE, Roberts IA, Amrolia P, Dokal I, Szydlo R, Darbyshire PJ. Bone marrow transplantation for $\beta$-thalassaemia major: The UK experience in two paediatric centres. Br J Haematol 2003; 120(2): 289-95.

DOI: $10.1046 / \mathrm{j} .1365-2141.2003 .04065 . \mathrm{x}$

[15] Cunningham MJ. Update on thalassemia: Clinical care and complications. Hematol/Oncol Clinics 2010; 24(1): 215-27. DOI: 10.1016/j.hoc.2009.11.006

[16] Cavazzana-Calvo M, Payen E, Negre O, et al. Transfusion independence and HMGA2 activation after gene therapy of human $\beta$-thalassaemia. Nature 2010; 467(7313): 318. DOI: 10.1038 /nature 09328

[17] Bank A, Dorazio R, Leboulch P. A Phase I/II clinical trial of $\beta$-globin gene therapy for $\beta$-Thalassemia. Ann NY Acad Sci 2005; 1054(1): 308-16. DOI: 10.1196/annals.1345.007

[18] Boulad F, Mansilla-Soto J, Cabriolu A, Rivière I, Sadelain M. Gene therapy and genome editing. Hematol/Oncol Clin North Am 2018; 32(2): 329-42 DOI: 10.1016/j.hoc.2017.11.007

[19] Lee C, Bao G, Porteus MH, et al. Gene editing with Crispr-Cas9 for treating Beta-Hemoglobinopathies. Am Soc Hematol 2015; 126: 3376

[20] Maeder ML, Gersbach CA. Genome-editing technologies for gene and cell therapy. Mol Ther 2016; 24(3): 430-6.

DOI: $10.1038 / \mathrm{mt} .2016 .10$

[21] Ansari SH, Shamsi TS, Ashraf M, et al. Efficacy of hydroxyurea in providing transfusion independence in $\beta$-thalassemia. $\mathrm{J}$ Pediat Hematol/Oncol 2011; 33(5): 339-43.

DOI: 10.1097/MPH.0b013e31821b0770

[22] Ansari SH, Shamsi TS, Siddiqui FJ, et al. Efficacy of hydroxyurea $(\mathrm{HU})$ in reduction of pack red cell (PRC) transfusion requirement among children having beta-thalassemia major: Karachi HU trial (KHUT). J Pediat Hematol/Oncol 2007; 29(11): 743-6. DOI: 10.1097/MPH.0b013e318157fd75

[23] Fibach E, Burke LP, Schechter AN, Noguchi C, Rodgers G. Hydroxyurea increases fetal hemoglobin in cultured erythroid cells derived from normal individuals and patients with sickle cell anemia or beta-thalassemia. Blood 1993; 81(6): 1630-5.

[24] Yavarian M, Karimi M, Bakker E, Harteveld CL, Giordano PC. Response to hydroxyurea treatment in Iranian transfusion-dependent beta-thalassemia patients. Haematologica 2004; 89(10): 1172-8.

[25] Zamani F, Shakeri R, Eslami S-M, Razavi S-M, Basi A. Hydroxyurea therapy in 49 patients with major beta-thalassemia. Arch Iran Med 2009; 12(3): 295-7.

[26] World Health Organization Human Genetics Programme. Proposed international guidelines on ethical issues in medial genetics and genetic service. Rev Derecho Genoma Hum 1998; (8): 219-23.

[27] Cousens NE, Gaff CL, Metcalfe SA, Delatycki MB. Carrier screening for beta-thalassaemia: A review of international practice. Eur J Hum Genetics 2010; 18(10): 1077. DOI: 10.1038/ejhg. 2010.90

[28] Karimi M, Jamalian N, Yarmohammadi H, Askarnejad A, Afrasiabi A, Hashemi A. Premarital screening for $\beta$-thalassaemia in Southern Iran: Options for improving the programme. J Med Screen 2007; 14(2): 62-6. DOI: $10.1258 / 096914107781261882$

[29] Angastiniotis M, Hadjiminas M. Prevention of thalassaemia in Cyprus. Lancet 1981; 317(8216): 369-71. DOI: 10.1016/S0140-6736(81)91682-2 
[30] Ginsberg G, Tulchinsky T, Filon D, Goldfarb A, Abramov L, Rachmilevitz E. Cost-benefit analysis of a national thalassaemia prevention programme in Israel. J Med Screen 1998; 5(3): 120-6. DOI: $10.1136 / j m s .5 .3 .120$

[31] Capua A. The montreal thalassemia screening program: Response of the high school students. Ann NY Acad Sci 1998; 850(1): 401-3. DOI: 10.1111/j.1749-6632.1998.tb10503.x

[32] BBC - Ethics - Abortion: Religion and abortion. [online] Available at: http://www.bbc.co.uk/ethics/abortion/religion/religion.shtml [Accessed 28/05/2018].
[33] Express Tribune [Internet]. [cited 28/05/2018]. Available from: https://tribune.com.pk/story/889024/per-capita-income-a-pakistani-now-makes-1513-a-year/.

[34] Shamsi T. Beta-thalassaemia--a major health problem in Pakistan. J Pak Med Assoc 2004; 54(10): 498.

[35] Ansari SH, Shamsi TS, Ahmed FN, Perveen K, Ahmed G. Effectiveness and feasibility of transabdominal chorionic villous sampling procedure for prenatal diagnosis of $\beta$-thalassaemia in a Muslim majority community of Pakistan. Pak J Med Sci 2012; 28(3): 575-9. 